\section{Effect of the application of the pediatric triage "JumpSTART" method on the readiness of initial handling of emergency cases in children}

\author{
Ani Sutriningsih, ${ }^{1}$ Setya Haksama, \\ Vita Maryah Ardiyani \\ ${ }^{1}$ Faculty of Public Health, Universitas \\ Airlangga; ${ }^{2}$ Faculty of Health Science, \\ Universitas Tribhuwana Tunggadewi, \\ Indonesia
}

\begin{abstract}
Emergency cases can happen unexpectedly, occur anywhere, and may put the school in danger. The schools should prepare themselves for emergencies including how to handle the situation. The aim of this study is to find the influence of the application of paediatric triage JumpSTART method on the readiness of the initial handling emergency cases on child. This study used an experimental research with pretest and posttest of one group design. The population covers the whole teachers and employees with the total of 21 respondents taken by using purposive sampling. Data was analyzed using the Marginal Homogenity test. The results of the research showed an effect of the Paediatric Triage JumpSTART method on the readiness of the initial handling of emergencies cases with $\mathrm{p}$ value 0.001 $(\mathrm{p}<0.05)$.
\end{abstract}

\section{Introduction}

School students are a group that is at high risk of emergencies. Academic institutions should be ready to manage the problems and improve the community awareness by forming synergistic partnerships between the schools and emergency practitioners. ${ }^{1}$ The word "triage" comes from the French of " trier" which means filtering or sorting. ${ }^{2}$ Triage is a process of classifying patients according to the level of severity and determining the priority for further treatment. ${ }^{3}$ Emergency is a condition that afflicts someone who can pose a threat to the soul, in the sense that it needs proper, accurate and precise help. Emergency can occur anywhere, anytime and to anyone, both everyday and mass disasters and disasters. ${ }^{4}$

Emergency cases that often occur in children at school include fainting, choking, fever, epistaxis, torn wounds, and vomiting.
Emergency events in schools can occur at any time so there is a need for the teachers and employees' readiness at school in the initial handling of emergencies before the child is taken to a health facility. Readiness is the whole condition (mental, physical, learning, and intelligence) to provide a response or answer in a particular way to a situation. Readiness for initial handling of emergencies including the release of airway, breathing function, circulation and disability. One of the triage methods for children is Jump Simple Triage and Rapid Treatment (JumpSTART). JumpSTART is widely used in the United States and Canada and is a modification of the START system. This tool is used for children aged 1 to 8 years. Additional modifications and assessments are needed for children less than 1 year of age, with developmental delay, chronic disability or injury. ${ }^{4}$

Primary School I (Sekolah Dasar Negeri (SDN)) Purwosari I is a superior elementary school in Purwosari Subdistrict, Pasuruan District with the number of 496 students and 21 teachers. From the results of a preliminary study, it was found that emergency cases were found in the last five years experienced by students including trauma cases such as head injuries, torn wounds, epitaxis and bone fractures while for cases of nontrauma includes vomiting, diarrhea, and fever. Based on the interviews with 10 teachers SDN Purwosari I, all $(100 \%)$ of the teachers stated that the handling of emergency cases in school just based on common knowledge and there is no medical personnel on duty at the school. The majority teachers $(80 \%)$ did not know how to handle the initial emergency based on the principles of initial handling of emergencies.

\section{Materials and Methods}

\section{Study design and targeted population}

This was an experimental research with one group pretest and posttest design approach . At the time of the study, there were 16 teachers and employees who are active in the Academic Year of 2017/2018 at SDN Purwosari I Pasuruan.

\section{Data collections procedure}

Data was collected between May - June 2018. The study variables include participants' socio-demographic characteristics (age, gender, level of education, experience Emergency First Aid training (PPGD) and handling emergency cases). The instrument in this study consisted of Standard Operating Procedure (SOP) which was used
Correspondence: Ani Sutriningsih, Doctoral Program of Public Health, Faculty of Public Health, Universitas Airlangga, Jl. Mulyorejo, Surabaya, Jawa Timur 60115, Indonesia.

Tel. +62.31.5920948, 5920949 -

Fax: +62.31 .5924618 .

E-mail: ani.sutriningsih-2018@fkm.unair.ac.id

Key words: triage, readiness, initial handling, emergency.

Acknowledgements: the authors would like to thank the Directorate General of Strengthening for Research and Development, Ministry of Research, Technology, and Higher Education of the Republic of Indonesia that has funded this research.

Contributions: the authors contribute equally.

Conflict of interests: the authors declare no potential conflict of interests.

Clinical trials: the study is not involved any clinical trials.

Funding: the work is supported by a Beginner Lecturer Research (Penelitian Dosen Pemula (PDP)) Grant, no. 95/TB-LPPM/TU220/III/2018.

Conference presentation: part of this paper was presented at the $3^{\text {rd }}$ International Symposium of Public Health, 2018 October 31 - November 1, Universitas Airlangga, Surabaya, Indonesia.

Dedication: the article is dedicated to Doctoral Program of Public Health, Faculty of Public Health, Universitas Airlangga, Surabaya, Indonesia; and Faculty of Health Science, Universitas Tribhuwana Tunggadewi, Indonesia.

Received for publication: 28 July 2019.

Revision received: 9 September 2019.

Accepted for publication: 15 October 2019.

This work is licensed under a Creative Commons Attribution NonCommercial 4.0 License (CC BY-NC 4.0).

(C) Copyright: the Author(s), 2019

Licensee PAGEPress, Italy

Journal of Public Health in Africa 2019; 10(s1):1173 doi:10.4081/jphia.2019.1173

to guide the implementation of the Pediatric Triage application JumpSTART method as well as questionnaires and observation sheets which were used to collect the data on the readiness of initial handling of emergencies in children compiled by the researcher based on literature review consisting of 10 items questions that have been tested for its validity and reliability. 


\section{Analytical approach}

Data was analyzed using the Marginal Homogenity test with the significance level obtained p-value $0.001<(\alpha 0.05)$.

\section{Ethical consideration}

Ethics research was carried out by applying the principle respect for person, maleficence, beneficence, honesty, and accuracy.

\section{Results}

\section{Socio-demographic characteristic of} participants

Overall, 16 teachers and employees were enrolled in the study. Table 1 resumes the socio-demographic characteristics of the study population. Based on the age, it obtains that the average age is 39.75 years, in which more than half $(81.25 \%)$ are female. All $(100 \%)$ have a final education of bachelor degree, and almost all (93.75\%) of them did not have any experience of Emergency First Aid training (PPGD) or to handle previous emergency cases.

\section{Readiness of initial handling of emergency cases before giving the paediatric triage JumpSTART method}

Based on the results of the readiness of initial handling emergency cases on children before giving the Paediatric Triage JumpSTART Method can be seen in Figure 1.

Based on the Figure 1, prior to Paediatric Triage JumpSTART Method, half of the respondents had a poor readiness to handle the initial emergency cases (50\%).

\section{Readiness of initial handling of emergency cases after giving the paediatric triage JumpSTART method}

The results of the readiness of initial handling emergency cases on children after giving the Paediatric Triage JumpSTART Method can be seen in Figure 2.

Based on Figure 2, after the Paediatric Triage JumpSTART Method, more than half of the respondents had a good category of readiness to handle the initial emergency cases $(56 \%)$.

Data analysis to determine the effect of the Paediatric Triage Jump START Methodon the readiness of the initial handling of emergencies in children in this study used Marginal Homogenity Test which obtained $p$ value of $0.001<(\alpha 0.05)$, which means that $\mathrm{H}_{0}$ is rejected so that there is an effect of the Pediatric Triage application JumpSTART method on the readiness of the initial handling of emergencies in children in SDN Purwosari I Pasuruan.

\section{Discussion}

Based on the results of the study, prior to Paediatric Triage JumpSTART Method, half of the respondents had a poor readiness to handle the initial emergency cases $(50 \%)$. Factors affecting emergency response readiness include knowledge, infrastructure, communication factors, and geographical factors. Based on the results of the study, almost all respondents $(93.75 \%)$ never had the experience of attending Emergency First Aid training (Pertolongan Pertama Gawat Darurat (PPGD)) and almost all respondents (93.75\%) had never had any experience dealing with previous emergency cases. Knowledge is the result of knowing, and this happens after people sensing a particular object. Knowledge is also very close to education both obtained through formal and informal education. ${ }^{5}$ Knowledge about first aid for emergencies can be obtained from the source of information or experience obtained at the environment. The high percentage of respondents who have never been exposed to information or emergency cases causes a lack of knowledge of respondents regarding the initial handling of emergencies.

Table 1. Socio-demographic characteristics of study population.

\begin{tabular}{lcc}
\hline Characteristics & n. \\
\hline Age & & \\
28 - 59 years (average 39.75 years) & 16 & 100 \\
Gender & & \\
M & 3 & 18.75 \\
F & 13 & 81.25 \\
Level of education & & \\
S1 & 16 & 100 \\
Experience participating in Emergency First Aid training & \\
Ever & 1 & 6.25 \\
Never & 15 & 93.75 \\
Experience handling emergency cases & & \\
Ever & 1 & 6.25 \\
Never & 15 & 93.75 \\
\hline
\end{tabular}
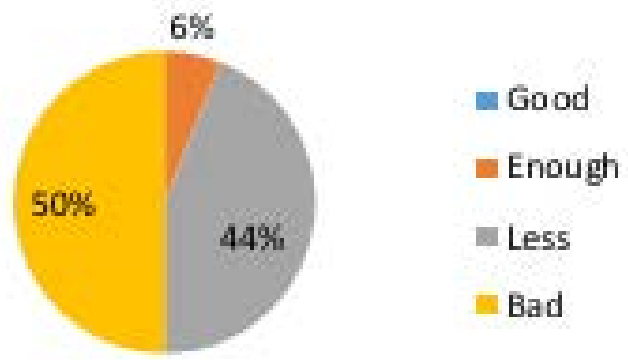

Figure 1 . Readiness of initial handling emergency cases on children before giving the Paediatric Triage JumpSTART Method.

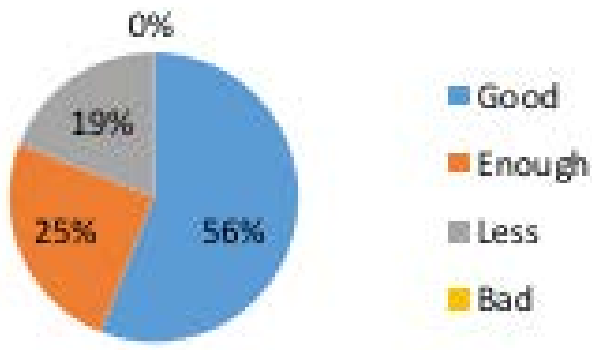

Figure 2. Readiness of initial handling emergency cases on children after giving the Paediatric Triage JumpSTART Method. 
Based on the general description of the research location at SDN Purwosari 1 Pasuruan there is School Health Unit (Unit Kesehatan Sekolah (UKS)) which serves for the students who are sick. In addition there is also a first aid tool on accident (Pertolongan Pertama pada Kecelakaan $(\mathrm{P} 3 \mathrm{~K})$ ) but inadequate for the initial handling of emergency cases. Based on the results of the interview, before being given training, the teacher provides first aid emergency cases to students in a way bring students who fainted into space UKS, lying on the bed, loosening clothes, giving effect, give pain stimulation if unconscious. Additionally, this is done without looking at the student's level of emergency.

After the Paediatric Triage JumpSTART Method, more than half of the respondents had a good category of readiness to handle the initial emergency cases $(56 \%)$. One factor that influences emergency response readiness is knowledge. Knowledge is also very close to education both obtained through formal and informal education. ${ }^{5}$ In this study, respondents were given the Paediatric Triage JumpSTART Method with lecture, question and answer, and demonstration methods that allowed respondents to obtain information both cognitive and psychomotor. Evaluation of the readiness of the initial handling of emergency cases using an observation sheet consists of 10 questions with a case including identification of problems and initial handling of airway,breathing, circulation, disability and conducting an emergency level assessment victim. The main aspect of triage is the initial assessment. Initial assessment is the main determinant of the next step of intervention. Aspects that must be studied when conducting initial assessments include mood, affect, perception, cognitive function, anxiety, acute psychotic and personality disorders. Assessment of these aspects certainly requires the development of knowledge. ${ }^{6}$ After training, respondents can demonstrate emergency first aid from the airway, breathing, circulation and awareness. In the training, an example of an emergency case in the child was first given determining the level of emergency of the child based on the Triage JumpSTART method.

The results of research by Ogbe stated that the readiness of primary schools in Delta State is still in its infancy. It is recommended that elementary schools have to provide at least one school health nurse in each primary school and school health teachers are given training opportunities in first aid and school health emergencies. ${ }^{7}$ Based on the results of these studies, it is important to hold emergency training in elementary schools. In addition, first aid kits are also important in supporting the initial handling of emergency cases in children.

Based on the results of the study, respondents stated that after attending the training they were aware of the signs of an emergency in the child and could demonstrate how to provide early handling of emergency cases and were ready to provide first aid. In addition, the respondents already knew about the condition of the emergency that had to be referred to the nearest health center or hospital to the school.

The amount of readiness of the research subjects before being given the application is half or 8 people have readiness at a level that is not good and after being given an application increases to 4 people at a good level, and each 2 people at a level sufficient and less. At 95\% confidence level using the Marginal Homogenity Test, p value $0.001<$ $(\alpha 0.05)$ was obtained, meaning that $\mathrm{HO}$ is rejected so that there is an effect of the Paediatric Triage application JumpSTART method on the readiness of the initial handling of emergencies in children in SDN Purwosari I Pasuruan. The results of this study are in accordance with the theory of Notoatmodjo that knowledge is very close to education both obtained through formal and informal education. ${ }^{5}$ Readiness of research subjects increased apart from knowledge when the application was given and shown in several emergency cases and the tools used as initial management in cases of emergency in children.

Factors that influence triage are internal factors including psychomotor abilities and personal capacity, while external factors are the environment. Erroneous decision making, especially in the category of victims/ victims in the poor triage category causes delays in treatment and disability and permanent disability for patients/ victims.

The results of this study are in accordance with the research conducted by Murtaqib and Widayati that there are differences in the preparedness for flood disasters before and after being given training. ${ }^{8}$ Another suitable study is Sasikome, Kumaat, \& Mulyadi's which concluded that there is an influence of flood disaster counseling on student preparedness. ${ }^{9}$ The results of this study are in line with research conducted by Sai, Kundre, \& Hutauruk indicating that there is influence health education and simulation of help knowledge and skills first in students with syncope in SMA 7 Manado.10 This is in line with research that mentions health education and simulation knowledge about dressing the first aid fracture on grade X students of SMK Negeri 6 Manado. ${ }^{11}$

The results of the above research can be seen that training is very influence on readiness in providing early handling of emergencies in children. Readers' readiness increases more through response and participation in attending the training, curiosity and intention to learn shown by respondents through simulation. Respondents attended training and were active in discussions. In a part, a number of respondents did a simulation with good judgment do accordingly the material they follow.

Based on this study researchers argue that the more increase the respondents' readiness on the initial handling of the emergency, the more increased their courage in giving first aid in deep children serious condition. The difference occurred in this study between before and after training provision is that the respondents experienced an increase of readiness, in which before being given the training, most respondents have bad readiness and more experience improvement through assessment after giving training through filling in the observation sheet.

\section{Conclusions}

There is an effect of the Paediatric Triage JumpSTART method on the readiness of the initial handling of emergencies cases in our study population.

\section{References}

1. Austin EN, Bastepe-Gray SE, Nelson HW, et al. Pediatric Mass-Casualty Education: Experiential Learning Through University-Sponsored Disaster Simulation. J of Emergency Nursing 2014;40(5):428-33.

2. Ryan JM. Triage: Principles and Pressures. European J of Trauma and Emergency Surgery 2008;34(5):27-32.

3. Lossius HM, Rehn M, Tjosevik KE, et al. Calculating trauma triage precision: effects of different definitions of major trauma. J of Trauma Management \& Outcomes 2012;6(9),1-7.

4. Stein L. Mass Casualty Triage. The Oklahoma Nurse 2008;53(2):18-21.

5. Notoatmodjo. Metodologi Penelitian Kesehatan. Jakarta: PT Rineka Cipta; 2010.

6. Sands N. An Exploration of Clinical Decision Making in Mental Health Triage. Archives of Psychiatric Nursing 
2009;23(4):298-308.

7. Ogbe JO. Primary Schools Readiness for Health Emergencies among Primary Schools in Delta State, Nigeria. J of Education and Social Research 2019;9(1),37-44.

8. Murtaqib, Widayati N. Pengaruh Pelatihan Terhadap Kesiapsiagaan Menghadapi Bencana Banjir pada Siswa di Pondok Pesantren Al Hasan I dan Al Hasan II Panti Jember. Prosiding
HEFA 2017:288-93.

9. Sasikome JR, Kumaat LT, Mulyadi. Pengaruh Penyuluhan Bencana Banjir Terhadap Kesiapsiagaan Siswa SMP Katolik Sogiyo Pranoto Manado Menghadapi Banjir. J Keperawatan 2015;3(2):1-8.

10. Sai IY, Kundre R, Hutauruk M. Pengaruh Pendidikan Kesehatan dan Simulasi terhadap Pengetahuan dan Keterampilan Pertolongan Pertama pada Siswa yang mengalami Sinkop di SMA Negeri 7 Manado. J Keperawatan 2018;6(2):1-8.

11. Warouw JA, Kumaat LT, Pondaag L. Pengaruh Pendidikan Kesehatan dan Stimulasi terhadap Pengetahuan tentang Balut Bidai Pertolongan Pertama Fraktur Tulang Panjang pada Siswa Kelas X SMK Negeri 6 Manado. J Keperawatan 2018;6(1):1-8. 